\title{
Antihistamine use in children
}

\author{
Roisin Fitzsimons, ${ }^{1,2}$ Lauri-Ann van der Poel, ${ }^{1}$ William Thornhill, ${ }^{3}$ \\ George du Toit, ${ }^{1,2}$ Neil Shah, ${ }^{4,5}$ Helen A Brough ${ }^{1,2}$
}

\begin{abstract}
${ }^{1}$ Children's Allergy Service, Guy's and St. Thomas' NHS Foundation Trust, London, UK ${ }^{2}$ Department of Asthma, Allergy and Respiratory Science, King's College London, London, UK ${ }^{3}$ Evelina Children's Pharmacy, Guy's and St. Thomas' NHS Foundation Trust, London, UK ${ }^{4}$ Department of Gastroenterology, Great Ormond Street Hospital, London, UK ${ }^{5}$ TARGID, Catholic University of Leuven, Leuven, The Netherlands
\end{abstract}

\section{Correspondence to}

Dr Helen A Brough,

Children's Allergy Service, Guy's and St Thomas' NHS Foundation Trust, 2nd Floor, Stairwell B, South Wing, Westminster Bridge Road, London SE1 7EH, UK; helen.brough@gstt.nhs.uk

RF and L-AvdP have contributed equally.

Received 28 February 2014 Revised 17 July 2014 Accepted 28 July 2014 Published Online First 21 August 2014

\section{CrossMark}

To cite: Fitzsimons $R$, van der Poel L-A, Thornhill W, et al. Arch Dis Child Educ Pract Ed 2015:100:122-131.

\section{ABSTRACT}

This review provides an overview of the use of antihistamines in children. We discuss types of histamine receptors and their mechanism of action, absorption, onset and duration of action of first-generation and second-generation $\mathrm{H}(1)$-antihistamines, as well as elimination of $\mathrm{H}(1)$-antihistamines which has important implications for dosing in children. The rationale for the use of $\mathrm{H}(1)$-antihistamines is explored for the relief of histamine-mediated symptoms in a variety of allergic conditions including: nonanaphylactic allergic reactions, atopic eczema $(A E)$, allergic rhinitis $(A R)$ and conjunctivitis, chronic spontaneous urticaria (CSU) and whether they have a role in the management of intermittent and chronic cough, anaphylaxis, food protein-induced gastrointestinal allergy and asthma prevention. Second-generation $\mathrm{H}(1)$ antihistamines are preferable to first-generation $\mathrm{H}(1)$-antihistamines in the management of nonanaphylactic allergic reactions, AR, AE and CSU due to: their better safety profile, including minimal cognitive and antimuscarinic side effects and a longer duration of action. We offer some guidance as to the choices of $\mathrm{H}(1)$-antihistamines available currently and their use in specific clinical settings. $\mathrm{H}(1)$-antihistamine class, availability, licensing, age and dosing administration, recommended indications in allergic conditions and modalities of delivery for the 12 more commonly used $\mathrm{H}(1)$-antihistamines in children are also tabulated.

\section{INTRODUCTION}

$\mathrm{H}(1)$-antihistamines are among the most commonly prescribed medicines in children. ${ }^{1}$ Indications include acute allergic reactions in food allergy, allergic rhinitis (AR) and chronic spontaneous urticaria (CSU); they are also used for relief of histamine-mediated symptoms, but are not the drug of first choice, in the context of atopic eczema (AE) and anaphylaxis. The International Study for Asthma and Allergies in Childhood (ISAAC) has shown a world-wide trend for increasing symptoms of eczema and
AR in childhood. ${ }^{2}$ In the UK, the Phase 3 (2002-2003) ISAAC study found a $10.1 \%$ prevalence of AR symptoms and $16 \%$ eczema symptoms in 6-year-old to 7-year-old children. ${ }^{2}$ Hospital admissions for food allergic reactions in the UK have increased by $500 \%$ between 1990 and 2003. ${ }^{3}$ In the last decade, the body of knowledge of the safety and efficacy of $\mathrm{H}$ (1)-antihistamines has increased substantially. ${ }^{4-6}$

\section{HISTAMINE AND THE ALLERGIC RESPONSE}

Histamine is a fundamental mediator in the pathophysiology of allergic condition in the smooth muscle, mucosa and skin (figure 1). On allergen exposure, an antigen cross-links specific immunoglobin $\mathrm{E}$ (IgE) bound to the surface of mast cells and basophils and leads to degranulation with release of histamine and other proinflammatory mediators. Once released, histamine binds to G-protein-coupled receptors on a wide variety of cells within the surrounding tissues and vasculature.

\section{TYPES OF HISTAMINE RECEPTORS}

Four types of histamine receptors have been identified, which have varying degrees of responsibility for mediating an allergic response. ${ }^{4-6} \mathrm{H} 1$ and $\mathrm{H} 2$ receptors are present on a wide range of cells (endothelial, epithelial, smooth muscle, neurons and cells of the innate and acquired immune system) and when in an active state, stimulate both the early phase of an allergic response (vasodilatation leading to erythema, swelling and hypotension) and the late-phase response, by upregulating cytokine production and cell-adhesion molecules, leading to a proinflammatory state. ${ }^{4}{ }^{5} \mathrm{H}(2)$-receptor antagonists, such as ranitidine, work primarily on gastric mucosa, inhibiting gastric secretion. $\mathrm{H} 3$ and $\mathrm{H} 4$ receptors are less widely expressed but are inducers of pruritus and proinflammatory immune 


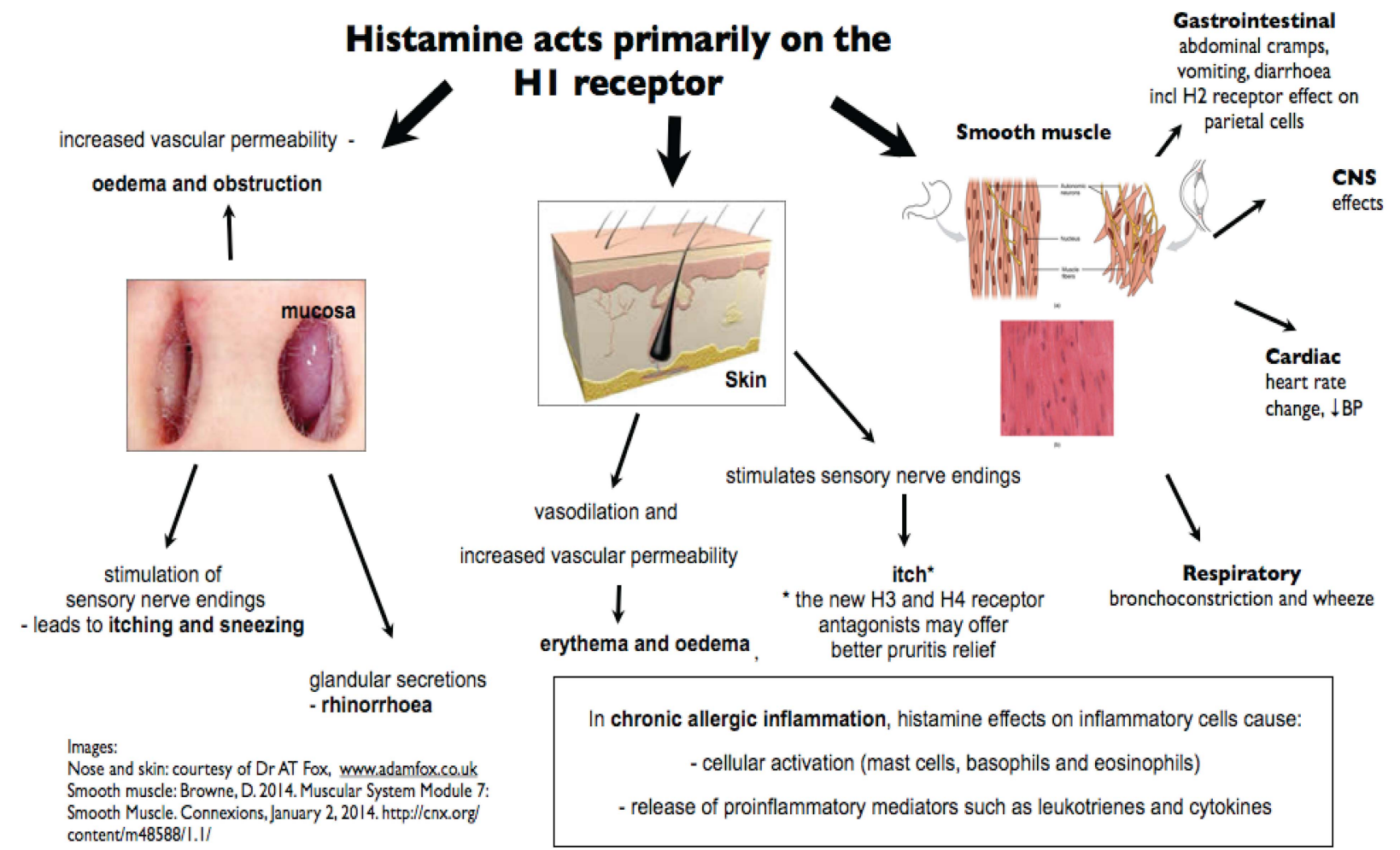

Figure 1 Effects of histamine in allergic disease.

responses. ${ }^{4} 5$ The therapeutic potential of targeting these new histamine receptors is yet to be fully elucidated. ${ }^{7}$

\section{ANTIHISTAMINE DRUGS AND MECHANISM OF ACTION}

Nobel Prize winner Daniel Bovet, a Swiss-born Italian pharmacologist, is best known for his synthesis and testing of antihistamines in 1937. Antihistamines were once considered histamine receptor antagonists; however, they have been reclassified as inverse agonists that have an affinity for G-protein-coupled histamine receptors, to which they bind, returning equilibrium to the cell and reducing the effects of an allergic response. ${ }^{4}{ }^{5} \mathrm{H}(1)$-antihistamines, thereby, inhibit respiratory, vascular and gastrointestinal smooth muscle constriction and decrease histamine-activated salivary and lacrimal gland secretions.

$\mathrm{H}(1)$-antihistamines are generally categorised as old or first-generation or new, second-generation $\mathrm{H}(1)$ antihistamines. The first generation of $\mathrm{H}(1)$-antihistamines have poor receptor selectivity for the $\mathrm{H}(1)$-receptor, occupying muscarinic cholinergic, $\alpha$-adrenergic, serotonin receptors and ion channels. ${ }^{48}$ Additionally, first-generation $\mathrm{H}(1)$-antihistamines are lipophilic, facilitating crossing of the blood-brain barrier into the central nervous system. ${ }^{4}{ }^{8}$ Studies looking at the binding to $\mathrm{H}(1)$-receptors in the brain in adults have shown between $50 \%$ and $90 \%$ occupancy by first-generation $\mathrm{H}(1)$-antihistamines, ${ }^{9}$ compared with $30 \%$ cetirizine and a negligible amount for fexofenadine using positron emission tomography. These older $\mathrm{H}(1)$-antihistamines may therefore be used for nausea (promethazine), migraine (pizotifen) and as preoperative medication, but the multiple receptor binding also means potential for related adverse effects (table 1).

In the 1980s, new $\mathrm{H}(1)$-antihistamines were developed to be minimally sedating or non-sedating, with limited blood-brain barrier penetration by addition of a carboxylic moiety with a protonated amine, reducing the drug's blood-brain barrier penetration capacity and increasing $\mathrm{H}(1)$-selectivity. ${ }^{11}$ Consensus on the use of these second-generation $\mathrm{H}(1)$-antihistamines was published in $2003 .{ }^{12}$ Some texts refer to the active metabolites derived from second-H(1)-generation antihistamines as 'thirdgeneration' $\mathrm{H}(1)$-antihistamines (desloratadine, levocetirizine and fexofenadine), but they are more commonly classified under the second-generation $\mathrm{H}(1)$-antihistamine category.

\section{PHARMACOKINETICS AND PHARMACODYNAMICS OF H(1)-ANTIHISTAMINES}

\section{Absorption}

Despite the longevity of their use, little is known about the pharmacokinetics and pharmacodynamics of first-generation $\mathrm{H}(1)$-antihistamines in young children and infants. Second-generation $\mathrm{H}$ (1)-antihistamines have been studied more extensively in older children and adults, and in the case of 


\begin{tabular}{|c|c|c|c|c|c|}
\hline \multirow[t]{2}{*}{$\begin{array}{l}\text { First-generation } \\
\mathrm{H}(1) \text {-antihistamines }\end{array}$} & \multicolumn{5}{|c|}{$\begin{array}{l}\text { The most common adverse effect of the first-generation } \mathrm{H}(1) \text {-antihistamines is central nervous system depression, with effects varying from slight drowsiness to deep sleep. Paradoxical } \\
\text { stimulation may occasionally occur, especially at high doses. These sedative effects, when they occur, may diminish after a few days of treatment. } \\
\text { Other first-generation } \mathrm{H}(1) \text {-antihistamine side effects include headache, psychomotor impairment and anti-muscarinic effects, such as dry mouth, thickened respiratory-tract secretions, blurred } \\
\text { vision, urinary difficulty or retention, constipation and increased gastro-oesophageal reflux. } \\
\text { Other rare side effects of first-generation } \mathrm{H}(1) \text {-antihistamines include hypotension, palpitation, arrhythmias, extrapyramidal effects, dizziness, confusion, depression, sleep disturbances, } \\
\text { tremour, convulsions, hypersensitivity reactions (including bronchospasm, angio-oedema, anaphylaxis, rashes, and photosensitivity reactions), blood disorders and liver dysfunction. }\end{array}$} \\
\hline & $\begin{array}{l}\text { Proprietary } \\
\text { forms }\end{array}$ & Availability & Licensed indication & Licensing age & Children's dose ${ }^{1}$ (oral doses) \\
\hline $\begin{array}{l}\text { Chlorphenamine } \\
\text { (Chlorpheniramine) }\end{array}$ & $\begin{array}{l}\text { Non-proprietary } \\
\text { Piriton } \\
\text { Allerief }\end{array}$ & $\begin{array}{l}P \\
G S L\end{array}$ & $\begin{array}{l}\text { Symptomatic relief of allergy such as hay fever, urticaria, food allergy, } \\
\text { drug reactions, relief of itch associated with chickenpox }\end{array}$ & $\begin{array}{l}\text { Liquid } \\
1-18 \text { years } \\
\text { Tabs } \\
6-18 \text { years } \\
\end{array}$ & $\begin{array}{l}1 \text { month- } 2 \text { years } 1 \mathrm{mg} \text { twice daily } \\
2-6 \text { years } 1 \mathrm{mg} \text { every } 4-6 \mathrm{~h} \text {, max. } 6 \mathrm{mg} \text { daily } \\
6-12 \text { years } 2 \mathrm{mg} \text { every } 4-6 \mathrm{~h} \text {, max. } 12 \mathrm{mg} \text { daily } \\
12-18 \text { years } 4 \mathrm{mg} \text { every } 4-6 \mathrm{~h} \text {, max. } 24 \mathrm{mg} \text { daily } \\
\end{array}$ \\
\hline Hydroxyzine & $\begin{array}{l}\text { Atarax } \\
\text { Ucerax }\end{array}$ & POM & Pruritus & $1-18$ years & $\begin{array}{l}6 \text { months }-6 \text { years initially } 5-15 \mathrm{mg} \text { at night, increased if } \\
\text { necessary to } 50 \mathrm{mg} \text { daily in } 3-4 \text { divided doses } \\
6-12 \text { years initially } 15-25 \mathrm{mg} \text { at night, increased if necessary } \\
\text { to } 50-100 \mathrm{mg} \text { daily in } 3-4 \text { divided doses } \\
12-18 \text { years initially } 25 \mathrm{mg} \text { at night, increased if necessary to } \\
100 \mathrm{mg} \text { in } 3-4 \text { divided doses }\end{array}$ \\
\hline Ketotifen & \begin{tabular}{|l} 
Zaditen \\
eye drops- \\
Zaditen \\
\end{tabular} & $\begin{array}{l}\text { POM } \\
\text { POM }\end{array}$ & $\begin{array}{l}\text { Symptomatic relief of allergy, such as allergic rhinitis (AR) } \\
\text { eye drops—-seasonal allergic conjunctivitis }\end{array}$ & $\begin{array}{l}3-18 \text { years } \\
3-18 \text { years }\end{array}$ & $\begin{array}{l}3-18 \text { years } 1 \mathrm{mg} \text { twice daily } \\
3-18 \text { years apply twice daily }\end{array}$ \\
\hline Promethazine hydrochloride & $\begin{array}{l}\text { Non-proprietary } \\
\text { Phenergan }\end{array}$ & POM & $\begin{array}{l}\text { Symptomatic relief of allergy, such as hay fever, insomnia associated with } \\
\text { urticaria and pruritus }\end{array}$ & $2-18$ years & $\begin{array}{l}2-5 \text { years } 5 \mathrm{mg} \text { twice daily or } 5-15 \mathrm{mg} \text { at night } \\
5-10 \text { years } 5-10 \mathrm{mg} \text { twice daily or } 10-25 \mathrm{mg} \text { at night } \\
10-18 \text { years } 10-20 \mathrm{mg} 2-3 \text { times daily or } 25 \mathrm{mg} \text { at night } \\
\text { increased to } 25 \mathrm{mg} \text { twice daily if necessary }\end{array}$ \\
\hline $\begin{array}{l}\text { Second-generation } \\
\text { H(1)-antihistamines }\end{array}$ & \multicolumn{5}{|c|}{ Generally, the second-generation $\mathrm{H}(1)$-antihistamines have little or no side effect of drowsiness or antimuscarinic effect. } \\
\hline Cetirizine & $\begin{array}{l}\text { Non-proprietary } \\
\text { Piriteze } \\
\text { Benadryl for } \\
\text { children }\end{array}$ & $\begin{array}{l}\text { GSL } \\
P \\
\text { POM }\end{array}$ & Hay fever, chronic idiopathic urticaria, atopic eczema & $2-18$ years & $\begin{array}{l}1-2 \text { years } 250 \mu \mathrm{g} / \mathrm{kg} \text { twice daily } \\
2-6 \text { years } 2.5 \mathrm{mg} \text { twice daily } \\
6-12 \text { years } 5 \mathrm{mg} \text { twice daily } \\
12-18 \text { years } 10 \mathrm{mg} \text { once daily } \\
\end{array}$ \\
\hline Loratadine & $\begin{array}{l}\text { Non-proprietary } \\
\text { Loratadine } \\
\text { Allereze, Clarityn }\end{array}$ & $\begin{array}{l}\text { GSL } \\
\text { P } \\
\text { POM }\end{array}$ & $\begin{array}{l}\text { Symptomatic relief of allergy, such as hay fever, chronic idiopathic } \\
\text { urticaria }\end{array}$ & $2-18$ years & $\begin{array}{l}\text { 2-12 years } \\
\text { under } 30 \mathrm{~kg} 5 \mathrm{mg} \text { once daily } \\
\text { over } 30 \mathrm{~kg} 10 \mathrm{mg} \text { once daily } \\
12-18 \text { years } 10 \mathrm{mg} \text { once daily }\end{array}$ \\
\hline Fexofenadine & $\begin{array}{l}\text { Non-proprietary } \\
\text { Telfast }\end{array}$ & POM & $\begin{array}{l}\text { Symptomatic relief of seasonal AR } \\
\text { symptomatic relief of chronic idiopathic urticaria }\end{array}$ & $6-18$ years & $\begin{array}{l}6-12 \text { years } 30 \mathrm{mg} \text { twice daily } \\
12-18 \text { years } 120 \mathrm{mg} \text { once daily } \\
12-18 \text { years } 180 \mathrm{mg} \text { once daily }\end{array}$ \\
\hline
\end{tabular}


Table 1 Continued

\begin{tabular}{|c|c|c|c|c|c|}
\hline & Proprietary forms & Availability & Licensed indication & Licensing age & Children's dose ${ }^{1}$ (oral doses) \\
\hline Levocetirizine & Xyzal & POM & Symptomatic relief of allergy, such as hay fever, urticaria & $\begin{array}{l}\text { Liquid } \\
2-18 \text { years } \\
\text { Tablets } \\
6-18 \text { years } \\
\end{array}$ & $\begin{array}{l}2-6 \text { years } 1.25 \mathrm{mg} \text { twice daily } \\
6-18 \text { years } 5 \mathrm{mg} \text { once daily }\end{array}$ \\
\hline Desloratadine & \begin{tabular}{|l} 
Desloratadine \\
(non-proprietary). \\
Neoclarityn \\
\end{tabular} & POM & Hay-fever, chronic idiopathic urticaria & $1-18$ years & $\begin{array}{l}1-6 \text { years } 1.25 \mathrm{mg} \text { once daily } \\
6-12 \text { years } 2.5 \mathrm{mg} \text { once daily } \\
12-18 \text { years } 5 \mathrm{mg} \text { once daily }\end{array}$ \\
\hline Olopatadine & Opatanol & POM & Seasonal allergic conjunctivitis & $3-18$ years & $\begin{array}{l}\text { Child 3-18 years apply twice daily; max. duration of treatment } \\
4 \text { months }\end{array}$ \\
\hline Acrivastine & \begin{tabular}{|l} 
Non-proprietary \\
Acrivastine. \\
Benadryl allergy relief \\
\end{tabular} & \begin{tabular}{|l} 
GSL \\
P \\
POM
\end{tabular} & Hay fever, chronic idiopathic urticaria & $12-18$ years & $8 \mathrm{mg}$ three times a day \\
\hline Azelastine & $\begin{array}{l}\text { Optilast } \\
\text { Rhinolast } \\
\text { Dymista—with } \\
\text { fluticasone }\end{array}$ & $\begin{array}{l}\text { POM } \\
\text { POM } \\
\text { POM }\end{array}$ & $\begin{array}{l}\text { Allergic conjunctivitis, seasonal allergic conjunctivitis } \\
\text { Perennial conjunctivitisSeasonal and perennial AR } \\
\text { Moderate to severe seasonal and perennial AR, if monotherapy with } \\
\text { antihistamine or corticosteroid is inadequate }\end{array}$ & $\begin{array}{l}4-18 \text { years } \\
5-18 \text { years } \\
12-18 \text { years }\end{array}$ & $\begin{array}{l}\text { Child } 4-18 \text { years apply twice daily, increased if necessary to } 4 \text { times } \\
\text { daily } \\
\text { Child } 12-18 \text { years apply twice daily, increased if necessary to } 4 \text { times } \\
\text { daily; max. duration of treatment } 6 \text { weeks } \\
1 \text { spray into each nostril twice daily } \\
\text { Child } 12-18 \text { years } 1 \text { spray into each nostril twice daily }\end{array}$ \\
\hline
\end{tabular}

Availability based on UK licensing includes whether on prescription (POM), or over the counter medicines: including pharmacist only (P) and general sales list medicines (GSL), which varies depending on license, pack size and brands. The licensed age range also varies from brand to brand. The usual dosing for various age ranges is described at the time of publication. The Table comprises information from summary of product characteristics for

each $\mathrm{H}(1)$-antihistamine and other source references. ${ }^{10} 4849$ 
cetirizine, several studies have been conducted in younger children and infants down to 6 months of age. $^{13}$ Following oral administration of $\mathrm{H}$ (1)-antihistamines, absorption usually occurs between 1 and $3 \mathrm{~h}$, defined as the time taken to reach peak plasma concentration (Tmax). ${ }^{6}$ In 11 children aged 616 years, chlorphenamine took between 1 and $6 \mathrm{~h}$ (median $3 \mathrm{~h}$ ) to reach Tmax. ${ }^{9}$

Certain second-generation $\mathrm{H}(1)$-antihistamines reach peak plasma concentrations more rapidly; for levocetirizine, the mean Tmax was between 1 and $1.2 \mathrm{~h}$, and for cetirizine, the mean Tmax was $0.8-2 \mathrm{~h}$, depending on the age of the child and dose administered. ${ }^{6}$ In children aged between 6 and 24 months administered a single $0.25 \mathrm{mg} / \mathrm{kg}$ dose of cetirizine, the Tmax was mean \pm SD $2.0 \pm 1.3 \mathrm{~h}$. In children aged 5-12 years, those administered $5 \mathrm{mg}$ cetirizine had a Tmax of $1.4 \pm 1.1 \mathrm{~h}$, whereas those administered $10 \mathrm{mg}$ cetirizine had a Tmax of $0.8 \pm 0.4 \mathrm{~h} .{ }^{14}$ Thus, Tmax appears reduced by lower cetirizine dosage and possibly also by younger age (although these children also received a lower dose of the drug). Conversely, desloratadine and fexofenadine can take up to $3 \mathrm{~h}$ to reach Tmax. ${ }^{6}$ Food slows the absorption of $\mathrm{H}$ (1)-antihistamines.

\section{ONSET AND DURATION OF ACTION}

Absorption does not equate to onset of action, as this effect is exerted locally in the tissues. Thus, onset of action of $\mathrm{H}(1)$-antihistamines has been studied by observing in vivo inhibition of cutaneous wheal and flare responses. ${ }^{4-6}$ Commonly used first-generation $\mathrm{H}$ (1)-antihistamines have been shown to inhibit a wheal and flare response from $1 \mathrm{~h}$ after administration in older children. ${ }^{13}$ Second-generation $\mathrm{H}$ (1)-antihistamines have a varied onset of action in older children ranging from $0.5 \mathrm{~h}$ for cetirizine to $1 \mathrm{~h}$ for fexofenadine, loratadine and levocetirizine. ${ }^{13}$ To date, we could find no studies assessing timing of inhibition of wheal and flare with the use of $\mathrm{H}$ (1)-antihistamines in preschool children and infants. Second-generation $\mathrm{H}(1)$-antihistamines have a longer duration of action and longer plasma half-life than first-generation $\mathrm{H}(1)$-antihistamines. ${ }^{4-6}$

\section{BIOTRANSFORMATION}

All first-generation $\mathrm{H}(1)$-antihistamines and most second-generation $\mathrm{H}(1)$-antihistamines, undergo metabolism in the liver by the hepatic cytochrome P450 enzyme system. ${ }^{4-6}$ Loratadine undergoes extensive first-pass metabolism in the liver resulting in decarboxylation to a pharmacologically active conjugated metabolite, desloratadine, and it is excreted as its conjugated metabolite, with $<1 \%$ of its original substance being found in the urine. Cetirizine, levocetirizine and fexofenadine are not metabolised in the liver and are, therefore, excreted unchanged in the urine or faeces. ${ }^{4-6}$ Cetirizine is a metabolite of hydroxyzine and fexofenadine is the hydrochloride salt of terfenadine's active metabolite; thus, both antihistamines are already metabolites of an earlier $\mathrm{H}$ (1)-antihistamine.

There are a number of substances that are known to affect the hepatic cytochrome P450 enzyme system, either inhibiting or inducing its action, which in turn can affect the plasma concentrations of $\mathrm{H}$ (1)-antihistamines either causing toxicity or reducing their action. Appendix 1 in the British National Formulary for Children has an extensive list of interactions between $\mathrm{H}(1)$-antihistamines and other substances, ${ }^{10}$ including worsening sedation (alcohol, opioid analgesics, anxiolytics and hypnotics), increased antimuscarinic effects (tricyclic and monoamine oxidase inhibitor antidepressants), increased risk of ventricular arrhythmias ( $\beta$-blockers and antiarrhythmics) reduction in bioavailability (antacids for fexofenadine) and increased bioavailability (macrolide antibiotics, ketoconazole antifungal, antivirals and grapefruit juice for rupatadine). Grapefruit juice reduces fexofenadine bioavailability, due to direct inhibition of uptake by intestinal organic anion transporting polypeptide A. ${ }^{15}$ Sedative interactions apply to a lesser extent to second-generation than firstgeneration $\mathrm{H}(1)$-antihistamines; in general, due to the wider safety margin of second-generation $\mathrm{H}$ (1)-antihistamines, interactions are less likely to lead to serious side effects.

\section{TERMINAL ELIMINATION}

Terminal elimination of $\mathrm{H}(1)$-antihistamines varies depending on the drug and age of the individual. ${ }^{4-6}$ For most $\mathrm{H}(1)$-antihistamines, information regarding dosing in children has been extrapolated from studies looking at the safety and efficacy in the adult population. Long-term-safety of cetirizine and levocetirizine, however, has been studied more extensively in younger children aged 12-24 months old. ${ }^{16} \quad 17$ Cetirizine and its enantiomer, levocetirizine, are eliminated more rapidly in young children, where renal clearance is more rapid. ${ }^{22}$ This has implications for dosing in young children, and twice daily administration is recommended for cetirizine and levocetirizine to achieve efficacy in children up to 6 years of age (table 1). Renal impairment reduces $\mathrm{H}(1)$-antihistamine clearance.

Although $\mathrm{H}(1)$-antihistamines are rapidly eliminated from plasma, there is a residual effect of up to 7 days from $\mathrm{H}(1)$-receptor occupancy, continuing to have a local effect; ${ }^{4-6}$ this residual anti-inflammatory effect may be of therapeutic benefit when used for chronic allergic conditions, such as AR or CSU. ${ }^{18}{ }^{19}$ In a study to evaluate the potential anti-inflammatory activities of the newer antihistamines, desloratadine dosedependently inhibited specific cytokine release and the chemoattractants for human neutrophils and eosinophils. This in vitro work shows some promise, but 


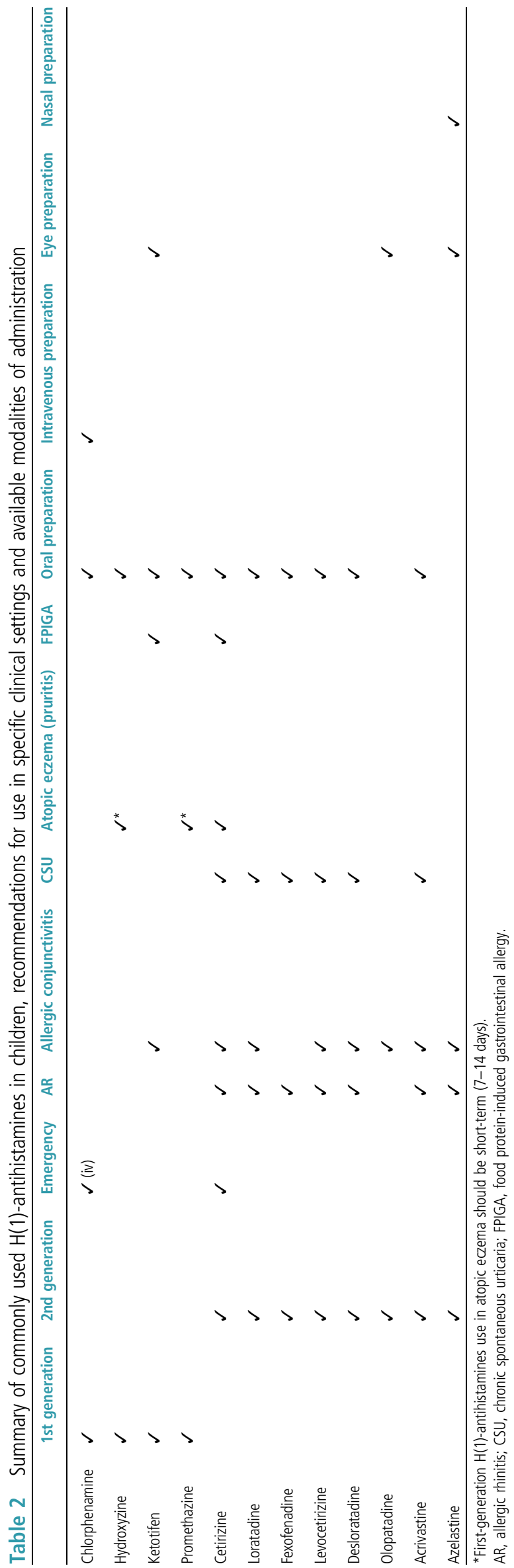

at doses higher than current clinical licensing recommends. ${ }^{20}$ There are other published reports of possible anti-inflammatory effects mediated through the H1 receptor, ${ }^{21}$ especially with regular over intermittent use, thus, more studies are needed to evaluate the anti-inflammatory properties of $\mathrm{H}(1)$-antihistamines in vivo.

\section{MEASURING EFFICACY}

There are no adequate objective measures of $\mathrm{H}$ (1)-antihistamine efficacy. Efficacy is subjective and is both patient-dependent and disease-dependent. Church and Maurer concluded that the clinical efficacy of an $\mathrm{H}(1)$-antihistamine could not be predicted solely from knowledge of its in vitro potency, and that in vivo inhibition of wheal and flare was a more accurate reflection of efficacy. ${ }^{22}$ However, in vivo efficacy is influenced by metabolism and excretion, lipid solubility, the degree and strength of binding to proteins and structural elements, penetration into and accumulation in the tissues and the local concentration of histamine in the tissues. Simons et $a l^{23}$ conducted a prospective, randomised, placebo-controlled, double-blind, crossover, single-dose study to evaluate the onset and duration of action of cetirizine and loratadine in 15 children (mean age of 9 years); the authors concluded that cetirizine and loratadine were both effective antihistamines in children aged 1224 months. For long-term conditions, the effect of $\mathrm{H}$ (1)-antihistamine may not be immediately apparent, and the use of quality of life (QoL) measures may facilitate a more accurate determination of efficacy, of which there are now several validated tools. ${ }^{18}$

\section{USE OF H(1)-ANTIHISTAMINES IN CLINICAL PRACTICE}

Despite first-generation $\mathrm{H}(1)$-antihistamines being in use for over 70 years, there are fewer studies assessing their pharmodynamics and safety profile. Second-generation $\mathrm{H}(1)$-antihistamines are the $\mathrm{H}$ (1)-antihistamines of choice for treatment of an allergic response due to their high selectivity for $\mathrm{H}$ (1)-receptors, efficacy and minimal side effects. There are several licensed indications for the use of $\mathrm{H}$ (1)-antihistamines in the paediatric population as described in table 1; however, we show our recommendations for their use in specific clinical settings (e.g. use in an emergency) in table 2. The most common route of administration of $\mathrm{H}$ (1)-antihistamines is oral, however, chlorphenamine can be administered intravenously and there are topical preparations available for ocular and nasal use for several $\mathrm{H}(1)$-antihistamines. Age of licensed use in children and dosage are displayed in table 1 ; there are doses available from 1 year of age for cetirizine, although the official licencing is from 2 years of age. The safety and efficacy profiles outlined for cetirizine 
suggest that this can be administered in this younger age group.

\section{ACUTE URTICARIA AND ALLERGIC REACTIONS}

Emergency treatment of non-anaphylactic IgE-mediated hypersensitivity reactions

$\mathrm{H}(1)$-antihistamines administered at the first sign of a non-anaphylactic allergic reaction may relieve immediate symptoms and possibly halt the progression onto a more severe allergic reaction, by inactivating the G-protein receptors and down-regulating the release of inflammatory mediators which, in turn, reduces the influx of inflammatory cells. The British Society of Allergy and Clinical Immunology (BSACI) allergy action plans (http://www.bsaci.org/about/ download-paediatric-allergy-action-plans) defaults to cetirizine for acute non-anaphylactic allergic reactions.

\section{ANAPHYLAXIS}

During anaphylaxis, several inflammatory mediators are released from degranulating mast cells and basophils; however, histamine maintains a pivotal role in inducing anaphylaxis. In fact, the signs and symptoms of anaphylaxis can be reproduced solely by histamine infusion. ${ }^{23}$ However, adrenaline remains the emergency medication of choice in anaphylaxis. $\mathrm{H}(1)$-antihistamines have a slower onset of action than intramuscular adrenaline and cannot block the effects of histamine once it has bound to the G-protein-coupled receptors on cells. Additionally, $\mathrm{H}(1)$-antihistamines provide none of the cardiovascular benefits of adrenaline.

The UK Resuscitation Council Guidelines for the Management of Anaphylaxis recommends intravenous chlorphenamine to follow intramuscular adrenaline and intravenous fluids. ${ }^{24} \mathrm{~A}$ number of guidelines recommend the use of $\mathrm{H}(1)$-antihistamines as an important treatment option in anaphylaxis. This recommendation is based on clinical experience but does not have a strong scientific basis; indeed, there might be no treatment effect, or the side effects might be worse than the treatment effect itself, particularly in the case of first-generation $\mathrm{H}(1)$-antihistamines. ${ }^{25} \mathrm{~A}$ Cochrane review was unable to find any randomised controlled trials comparing $\mathrm{H}(1)$-antihistamines with placebo in the management of anaphylaxis. ${ }^{26}$

\section{ALLERGIC RHINITIS (AR) AND CONJUNCTIVITIS}

AR reduces QoL and learning ability in children and is associated with poor examination performance in teenagers due to poor sleep quality and daytime somnolence; this has been shown to be compounded by first-generation $\mathrm{H}(1)$-antihistamines but not by second-generation $\mathrm{H}(1)$-antihistamines. ${ }^{25}$ A casecontrol study of 1834 students in the UK taking national examinations found that teenagers with untreated AR were $40 \%$ more likely to drop a grade or more compared with healthy teenagers. ${ }^{27}$
First-generation $\mathrm{H}(1)$-antihistamines increased the affected number of teenagers more likely to drop a grade to $70 \%{ }^{27}$ The Allergic Rhinitis and its Impact on Asthma group (ARIA) recommend secondgeneration $\mathrm{H}(1)$-antihistamines as the antihistamine treatment of choice for AR. ${ }^{18}$

Cetirizine, levocetirizine, fexofenadine and loratadine all have well-documented clinical efficacy in treating AR in children. ${ }^{13} 28$ The 2008 BSACI AR guidelines advise that the topical nasal $\mathrm{H}$ (1)-antihistamine azelastine is more effective in treating $\mathrm{AR}$ symptoms than oral $\mathrm{H}(1)$-antihistamines, however, is not as effective in treating allergic conjunctivitis. ${ }^{29}$ Intranasal steroids are far superior to $\mathrm{H}$ (1)-antihistamine alone in the treatment of AR, but there are combination intranasal $\mathrm{H}(1)$-antihistamine and steroid preparations showing good efficacy. ${ }^{30}$ For allergic conjunctivitis, olopatadine eye drops (through dual $\mathrm{H}(1)$-antihistamine mast cell stabilisation effects) are superior to sodium chromoglycate with good cost effectiveness and fewer general practitioner attendances in the olopatadine group. ${ }^{31}$

\section{ALLERGIC RHINITIS IN ASTHMA}

A population-based study over 12 months from a UK General Practice database found that children with physician-diagnosed AR were more than twice as likely to be hospitalised for asthma compared with asthmatic children without AR. ${ }^{32}$ Treatment with intranasal steroids and/or second-generation $\mathrm{H}$ (1)-antihistamines in children with asthma and AR has been shown to significantly reduce the risk of emergency care and hospital admission due to asthma exacerbations. ${ }^{33}$ It may be, therefore, that-as part of the 'united airway' concept-treatment of AR and reduction in nasal allergic inflammation may deliver some benefits on lung function in asthmatic children.

\section{ASTHMA PREVENTION}

The Early Treatment of the Atopic Child (ETAC) study was a randomised controlled study on the prevention of asthma by twice daily administration of cetirizine in children aged 12-24 months with AE. There was no difference in the cumulative prevalence of asthma between groups overall; however, in a posthoc analysis, they found a $50 \%$ reduction in the development of asthma symptoms compared with the placebo group, in a subset of children sensitised to grass pollen or house dust mite. ${ }^{16}$ These findings could not be replicated in the Early Prevention of Asthma in Atopic Children (EPAAC) study, where young children with $\mathrm{AE}$ sensitised to grass pollen and house dust mite were treated with levocetirizine; ${ }^{17}$ thus, $\mathrm{H}(1)$-antihistamines do not appear to have a role in the prevention of asthma. 


\section{INTERMITTENT AND CHRONIC COUGH}

$\mathrm{H}(1)$-antihistamines are not recommended as empiric treatment for chronic cough in children, contrasting with adult recommendations, unless postnasal drip is diagnosed in the context of AR. ${ }^{34}{ }^{35}$ Since February 2009, the Medicines and Healthcare products Regulatory Agency in the UK has advised that cough and cold remedies containing certain ingredients, including first-generation $\mathrm{H}(1)$-antihistamines, should no longer be used in children younger than 6 years of age, due to the unfavourable balance of benefit and risks.

\section{CHRONIC SPONTANEOUS URTICARIA}

CSU (previously known as chronic idiopathic urticaria) is defined as urticaria with daily, or almost daily, symptoms for more than 6 weeks. $^{36}$ The recommended first-line treatment for CSU is secondgeneration $\mathrm{H}(1)$-antihistamines. Data in adults comparing efficacy in CSU suggest using cetirizine over fexofenadine and levocetirizine over desloratadine and fexofenadine. ${ }^{37} 38$ If standard dosing is ineffective, increasing the daily dosage (by increasing frequency of dosage) up to fourfold may be recommended. ${ }^{19} 3639$ Current limited data suggest that higher doses of levocetirizine and desloratadine are more effective in CSU unresponsive to standard doses and that higher than recommended doses of fexofenadine offers no greater efficacy in symptom control. ${ }^{39}$ In patients who still remain unresponsive, use of another non-sedating $\mathrm{H}$ (1)-antihistamine is recommended. Second-line therapies, such as leukotriene receptor antagonists, and $\mathrm{H}$ (2)-antihistamines, such as ranitidine (Zantac), may be added to $\mathrm{H}(1)$-antihistamine treatment. These are sometimes used to treat CSU, as approximately 15\% of cutaneous receptors are $\mathrm{H}(2)$-receptors, but there is currently little published data on their efficacy in this context. ${ }^{40}$

\section{FOOD PROTEIN-INDUCED GASTROINTESTINAL ALLERGY}

Food protein-induced gastrointestinal allergy (FPIGA) is non- $\operatorname{IgE}$ mediated and may respond to specific dietary exclusions. For some patients, dietary exclusions may need to be accompanied by medications, including antihistamines, to control ongoing symptoms. ${ }^{41}$ There are several small studies on the use of antihistamines and mast cell stabilisers to control gastrointestinal symptoms thought to be caused by the interplay between the enteric nervous system and the mucosal immune system of the intestine. Ketotifen fumarate, a first-generation $\mathrm{H}(1)$-antihistamine, also has mast cell stabilisation effects and has been shown to have benefits in some patients with FPIGA. ${ }^{42}{ }^{43} \mathrm{In}$ a prospective study of 77 children, the additional benefit of ketotifen to carefully controlled elimination diets ranged from 52.1\% improvement in abdominal pain but only $17.2 \%$ improvement in vomiting. ${ }^{44}$ The
$\mathrm{H}(2)$-antihistamine commonly used in FPIGA is ranitidine, better recognised for its acid suppressive effects acting through $\mathrm{H}(2)$-receptor blockade. A word of caution is that there has been a reported increase in the incidence of food allergy associated with the use of excessive use of antacid treatments in both humans and animal models. ${ }^{45}$

\section{ATOPIC ECZEMA}

Current National Institute for Health and Care Excellence (NICE) guidance for AE in children does not recommend the routine use of oral $\mathrm{H}$ (1)-antihistamines in the management of $\mathrm{AE}^{46}$ however, a 1-month trial of a nonsedating $\mathrm{H}$ (1)-antihistamine may be offered to children with AE where there is severe itching or urticaria. NICE

\section{Key points}

The use of second-generation $\mathrm{H}(1)$-antihistamines, such as cetirizine, loratadine and fexofenadine should be first-line therapy for the management of urticaria secondary to food allergic reactions, allergic rhinitis or chronic spontaneous urticaria (CSU) in children.

- Cetirizine has at least as quick an onset of action as chlorphenamine, and is our preferred choice of second-generation $H(1)$-antihistamine for nonanaphylactic food allergic reactions in children due the body of literature on safety and pharmacokinetics available on this drug. It is also available in syrup form.

- Intramuscular adrenaline is the treatment of choice in the management of anaphylaxis. There is currently insufficient evidence on the benefit of $\mathrm{H}$ (1)-antihistamines in the treatment of anaphylaxis.

- First-generation $\mathrm{H}(1)$-antihistamines, such as chlorphenamine and hydroxyzine, are relatively nonspecific and lipophilic and are more likely to lead to central nervous system effects. The sedative effect of first-generation $\mathrm{H}(1)$-antihistamines may seem desirable or indicated (e.g. nocturnal relief in atopic eczema-related pruritis) but can disrupt sleep patterns and affect learning.

- Second-generation (non-sedating) $\mathrm{H}(1)$-antihistamines are well tolerated over a long period, and have fewer adverse effects on cognition, although some patients may still experience sedation.

- High doses of second-generation $\mathrm{H}(1)$-antihistamine are often necessary for symptomatic control of CSU and appear to be safe in up to four times the recommended daily dose.

- Emergency department-based comparative trials between first-generation and second-generation $\mathrm{H}(1)$ antihistamines would be useful. Parenteral forms of second-generation $\mathrm{H}(1)$-antihistamines are not currently available. 


\section{Multiple choice questions}

1. All second-generation $\mathrm{H}(1)$-antihistamines are licensed from 2 years of age.

2. In children up to 6 years of age, cetirizine and levocetirizine should be administered twice daily for optimum plasma concentrations as elimination of this $\mathrm{H}(1)$-antihistamine is faster.

3. In CSU, children may benefit from four times the recommended daily dose of non-sedating secondgeneration $\mathrm{H}(1)$-antihistamines if not controlled by standard doses of $\mathrm{H}(1)$-antihistamines.

4. Chlorphenamine has a faster onset of action than cetirizine.

5. Macrolide antibiotics may increase plasma concentrations of $\mathrm{H}(1)$-antihistamines.

Answers are on page 131.

guideline recommends that treatment may be continued, if successful, while symptoms persist, but that this should be reviewed every 3 months. For an acute flare of AE, NICE guidelines recommend that a sedating $\mathrm{H}(1)$-antihistamine may be trialled for 7-14 days in children over 6 months of age if sleep disturbance has a significant impact on the child, parents or carers. Hydroxyzine is a popular sedating $\mathrm{H}$ (1)-antihistamine choice; however, on the basis of the evidence presented in this review and others, ${ }^{47}$ regarding the non-selective effects of first-generation $\mathrm{H}(1)$-antihistamines, we recommend these effects should be discussed with the parents, and treatment with first-generation $\mathrm{H}(1)$-antihistamines should be avoided if possible.

\section{SUMMARY}

$\mathrm{H}(1)$-antihistamines are of major therapeutic value in the management of allergic conditions and have been in use for 70 years. The second-generation $(\mathrm{H})$ 1 -antihistamines have been available since the 1980s and should be used over first-generation (H) 1-antihistamines due to their more favourable side-effect profile, duration of action and safety record. While second-generation $\mathrm{H}(1)$-antihistamines are preferable even for emergency medication in an allergic reaction, no parenteral formulation is available. Before treatment with any antihistamine is commenced, the child and family should be counselled in appropriate use, that is, age of licensed use, frequency and dosing, clinical effects and possible side effects-especially in the case of first-generation $\mathrm{H}(1)$-antihistamines.

Contributors $\mathrm{HAB}$ wrote the abstract, introduction, summary and questions, and critically reviewed and amended the manuscript and references as a whole. RF wrote the sections on histamine receptors, mechanism of action and pharmacokinetics of antihistamines. L-AvdP created figure 1 and wrote the sections on clinical use of antihistamines and the Key Points.
WT created table 1 and the text for adverse effects of antihistamines. GdT wrote the section on chronic spontaneous urticaria and NS wrote the section on food protein-induced gastrointestinal allergy.

Competing interests $\mathrm{HAB}$ has received research grant support from Thermofisher Scientific, Stallergenes and Meridian Foods, conference fees from Meda, Thermofisher Scientific, Danone, Mead Johnson, Nutricia and consultancy/lecture fees from Meda, Thermofisher Scientific and ALK-Abello. RF has participated in expert panels for Nutricia, spoken for Stallergenes at educational meeting and has received educational sponsorship from ALK Abello. NS is on the Advisory Board for Mead-Johnson. LAvdP received conference fees from Nutricia.

Provenance and peer review Commissioned; externally peer reviewed.

\section{REFERENCES}

1 Helms PJ, Ekins DS, Taylor MW, et al. Utility of routinely acquired primary care data for paediatric disease epidemiology and pharmacoepidemiology. Br J Clin Pharmacol 2005;59:684-90.

2 Asher MI, Montefort S, Bjorksten B, et al. Worldwide time trends in the prevalence of symptoms of asthma, allergic rhinoconjunctivitis, and eczema in childhood: ISAAC Phases One and Three repeat multicountry cross-sectional surveys. [Erratum appears in Lancet 2007;370(9593):1128]. Lancet 2006;368:733-43.

3 Gupta R, Sheikh A, Strachan DP, et al. Time trends in allergic disorders in the UK. Thorax 2007;62:91-6.

4 Simons FE. Advances in H1-antihistamines. [Review] [120 refs]. N Engl J Med 2004;351:2203-17.

5 Simons FE, Simons KJ. H1 antihistamines: current status and future directions. World Allergy Organ J 2008;1:145-55.

6 Simons FE. Comparative pharmacology of $\mathrm{H} 1$ antihistamines: clinical relevance. [Review] [28 refs]. Am J Med 2002;113 (Suppl):46S.

7 Yu F, Bonaventure P, Thurmond RL. The future antihistamines: histamine $\mathrm{H} 3$ and $\mathrm{H} 4$ receptor ligands. [Review]. Adv Exp Med Biol 2010;709:125-40.

8 Church MK, Church DS. Pharmacology of antihistamines. Indian J Dermatology 2013;58:219-24.

9 Simons FE, Luciuk GH, Simons KJ. Pharmacokinetics and efficacy of chlorpheniramine in children. J Allergy Clin Immunol 1982;69:376-81.

10 Royal Pharmaceutical Society of Great Britain, RCPCH Publications Ltd, BMJ. British national formulary for children. BMJ Publishing Group Ltd, 2014.

11 Shimamura T, Shiroishi M, Weyand S, et al. Structure of the human histamine H1 receptor complex with doxepin. Nature 2011;475:65-70.

12 Holgate ST, Canonica GW, Simons FE, et al. Consensus Group on New-Generation Antihistamines (CONGA): present status and recommendations. [Review] [116 refs]. Clin Exp Allergy 2003;33:1305-24.

13 de Blic J, Wahn U, Billard E, et al. Levocetirizine in children: evidenced efficacy and safety in a 6-week randomized seasonal allergic rhinitis trial. Pediatr Allergy Immunol 2005; 16:267-75.

14 Watson WT, Simons KJ, Chen XY, et al. Cetirizine: a pharmacokinetic and pharmacodynamic evaluation in children with seasonal allergic rhinitis. J Allergy Clin Immunol 1989;84 (4:Pt 1):457-64.

15 Dresser GK, Bailey DG, Leake BF, et al. Fruit juices inhibit organic anion transporting polypeptide-mediated drug uptake 
to decrease the oral availability of fexofenadine. Clin Pharmacol Ther 2002;71:11-20.

16 Diepgen TL. Early Treatment of the Atopic Child Study Group. Long-term treatment with cetirizine of infants with atopic dermatitis: a multi-country, double-blind, randomized, placebo-controlled trial (the ETAC trial) over 18 months. Pediatr Allergy Immunol 2002;13:278-86.

17 Simons FE. Early Prevention of Asthma in Atopic Children (EPAAC) Study Group. Safety of levocetirizine treatment in young atopic children: An 18-month study. Pediatr Allergy Immunol 2007;18:535-42.

18 Brozek JL, Bousquet J, Baena-Cagnani CE, et al. Allergic Rhinitis and its Impact on Asthma (ARIA) guidelines: 2010 revision. J Allergy Clin Immunol 2010; 126:466-76.

19 Powell RJ, Du Toit GL, Siddique N, et al. BSACI guidelines for the management of chronic urticaria and angio-oedema. Clin Exp Allergy 2007;37:631-50.

20 Traidl-Hoffmann C, Munster I, Ring J, et al. Impact of desloratadine and loratadine on the crosstalk between human keratinocytes and leukocytes: Implications for anti-inflammatory activity of antihistamines. Int Arch Allergy Immunol 2006;140:315-20.

21 Canonica GW, Blaiss M. Antihistaminic, anti-inflammatory, and antiallergic properties of the nonsedating second-generation antihistamine desloratadine: a review of the evidence. World Allergy Organ J 2011;4:47-53.

22 Kearns GL, Abdel-Rahman SM, Alander SW, et al. Developmental pharmacology—drug disposition, action, and therapy in infants and children. [Review] [97 refs]. N Engl J Med 2003;349:1157-67.

23 Simons FER. H1-antihistamines in children. Histamine and H1-antihistamines in allergic disease. 2nd edn. New York: Marcel Dekker, Inc, 2002.

24 Soar J, Pumphrey R, Cant A, et al. Emergency treatment of anaphylactic reactions-guidelines for healthcare providers. Resuscitation 2008;77:157-69.

25 Church MK, Maurer M, Simons FE, et al. Risk of first-generation $\mathrm{H}(1)$-antihistamines: a $\mathrm{GA}(2) \mathrm{LEN}$ position paper. [Review] [77 refs]. Allergy 2010; 65:459-66.

26 Sheikh A, Ten Broek V, Brown SG, et al. H1-antihistamines for the treatment of anaphylaxis: Cochrane systematic review. [Review] [40 refs]. Allergy 2007;62:830-7.

27 Walker S, Khan-Wasti S, Fletcher M, et al. Seasonal allergic rhinitis is associated with a detrimental effect on examination performance in United Kingdom teenagers: case-control study. J Allergy Clin Immunol 2007;120:381-7.

28 Del Cuvillo A, Sastre J, Montoro J, et al. Use of antihistamines in pediatrics. [Review] [106 refs]. J Investig Allergol Clin Immunol 2007;17(Suppl):40.

29 Scadding GK, Durham SR, Mirakian R, et al. BSACI guidelines for the management of allergic and non-allergic rhinitis. Clin Exp Allergy 2008;38:19-42.

30 Ratner PH, Hampel F, Van BJ, et al. Combination therapy with azelastine hydrochloride nasal spray and fluticasone propionate nasal spray in the treatment of patients with seasonal allergic rhinitis. Ann Allergy Asthma Immunol 2008; 100:74-81.

31 Guest JF, Clegg JP, Smith AF. Health economic impact of olopatadine compared to branded and generic sodium cromoglycate in the treatment of seasonal allergic conjunctivitis in the UK. Curr Med Res Opin 2006;22:1777-85.
32 Thomas M, Kocevar VS, Zhang Q, et al. Asthma-related health care resource use among asthmatic children with and without concomitant allergic rhinitis. Pediatrics 2005;115:129-34.

33 Corren J, Manning BE, Thompson SF, et al. Rhinitis therapy and the prevention of hospital care for asthma: a case-control study. J Allergy Clin Immunol 2004;113:415-19.

34 Shields MD, Bush A, Everard ML, et al. British Thoracic Society Cough Guideline Group. BTS guidelines: recommendations for the assessment and management of cough in children. Thorax 2008;63(Suppl):iii15.

35 Chang AB, Peake J, McElrea MS. Anti-histamines for prolonged non-specific cough in children. [Review] [60 refs] [Update of Cochrane Database Syst Rev 2006;(3):CD005604; PMID: 16856107]. Cochrane Database Syst Rev 2008;(2):CD005604.

36 Zuberbier T, Asero R, Bindslev-Jensen C, et al. EAACI/GA(2) LEN/EDF/WAO guideline: management of urticaria. [179 refs]. Allergy 2009;64:1427-43.

37 Handa S, Dogra S, Kumar B. Comparative efficacy of cetirizine and fexofenadine in the treatment of chronic idiopathic urticaria. J Dermatol Treat 2004;15:55-7.

38 Church MK, Maurer M. H(1)-antihistamines and urticaria: how can we predict the best drug for our patient?. [Review]. Clin Exp Allergy 2012;42:1423-9.

39 Staevska M, Popov TA, Kralimarkova T, et al. The effectiveness of levocetirizine and desloratadine in up to 4 times conventional doses in difficult-to-treat urticaria. J Allergy Clin Immunol 2010;125:676-82.

40 Tsakok T, Du Toit G, Flohr C. Pediatric urticaria. Immunol Allergy Clin North Am 2014;34:117-39.

41 Meyer R, Scharz C, Shah N. A review on the diagnosis and management of food-induced gastrointestinal allergies. Curr Allergy Clin Immunol 2012;25:10-17.

42 Melamed I, Feanny SJ, Sherman PM, et al. Benefit of ketotifen in patients with eosinophilic gastroenteritis. Am J Med 1991;90:310-14.

43 Molkhou P, Dupont C. Ketotifen in prevention and therapy of food allergy. Ann Allergy 1987;59(5:Pt2):187-93.

44 Dominguez-Ortega G, Meyer R, Dziubak R, et al. Gastrointestinal food allergy assessment by a symptom questionnaire [abstract]. Allergy 2013;68(Suppl.97):333.

45 Untersmayr E, Jensen-Jarolim E. The role of protein digestibility and antacids on food allergy outcomes. [Review] [148 refs]. J Allergy Clin Immunol 2008;121:1301-8.

46 National Institute for Health and Clinical Excellence. Atopic eczema in children: Management of atopic eczema in children from birth up to the age of 12 years. 2007. http://www.nice. org.uk/guidance/CG57

47 Akdis CA, Akdis M, Bieber T, et al. Diagnosis and treatment of atopic dermatitis in children and adults: European Academy of Allergology and Clinical Immunology/American Academy of Allergy, Asthma and Immunology/PRACTALL Consensus Report. [Review] [200 refs]. Allergy 2006;61:969-87.

48 Chemists and Druggists. Guide to OTC Medicines and Diagnostics. 2014.

49 Royal Pharmaceutical Society. Legal classification of medicines. http://wwwrpharms.com/ (Accessed May 2014).

Answers to the questions on page 130

(1) False; (2) True; (3) True; (4) False; (5) True. 